\title{
Akılcı antibiyotik kullanımı konusunda aile hekimlerinin bilgi ve yaklaşımlarının değerlendirilmesi
}

\section{Evaluation of knowledge and approaches of family physicians on rational antibiotic use}

\author{
Handan ALAY*1 $\square$, Fatma KESMEZ CAN ${ }^{1} \square$, Zülküf KAYA² $\square$, Mahmut UÇAR $^{3}$ 回
}

${ }^{1}$ Atatürk Üniversitesi Tıp Fakültesi Hastanesi, Enfeksiyon Hastalıkları ve Klinik Mikrobiyoloji Anabilim dalı, Erzurum/TÜRKIYE

${ }^{2}$ Atatürk Üniversitesi Tıp Fakültesi Hastanesi, Kulak, Burun ve Boğaz Hastalıkları Anabilim dalı, Erzurum/TÜRKIYE

${ }^{3}$ Erzurum Ill sağlık Müdürlüğü

\section{ÖZ}

Amaç: Akılcı olmayan antibiyotik kullanımı sonucu ortaya çıkan antimikrobiyal direnç, tüm dünyada ve ülkemizde giderek artan önemli bir halk sağlığı sorunudur. Hastaya bağı faktörlerin yanında hekimlerin antibiyotik reçete etme konusundaki bilgi ve tutumları akılcı olmayan antibiyotik kullanımını artırmaktadır. Bu çalışmada amacımız ilimizdeki aile hekimlerinin antibiyotik reçete etme konusundaki bilgi, tutum ve davranışlarını belirleyerek akılcı antibiyotik kullanımı konusunda hekimlerin farkındalığını artırmaktır.

Gereç ve Yöntemler: Hekimlerin antibiyotik reçete etmedeki bilgi düzeyleri ve davranışları konusunda 19 sorudan oluşan anket formu oluşturuldu. 29.12.2018-01.05.2019 tarihleri arasında 180 aile hekimi anketi doldurmayı kabul etti.

Bulgular: Aile hekimlerinin 106 (\%58,9)'u erkek, 74 (\%41,1)'i kadındı. Yaş ortalamaları 33 1 (min: 24- max: 50) yıl ve ortalama hizmet süreleri 103 \pm 1 (min:1-max:300) ay idi. Hekimlerin günlük hasta sayısı ortalaması $77 \pm 1$ idi. Hekimlerin $137(\% 76,1)^{\prime} i$ il merkezinde, $43(\% 23,9)^{\prime}$ 'u ilçede görev yapmaktaydı. Hekimlerin en sık karşılaştıkları enfeksiyon tipleri 134 (\%37.5) üst solunum yolu enfeksiyonu ve 61(\%17.1) üriner sistem enfeksiyonu idi. En sık reçete ettikleri antibiyotikler beta laktam grubu antibiyotikler idi. Hekimlerin 109 (\%60.6)'u mezuniyet sonrası eğitim almadıklarını, 147(\%81.7)'si akılcı antibiyotik kullanımı konusunda mezuniyet sonrası hizmet içi eğitimlerin faydalı olduğunu belirttiler. Hekimlerin 93 (\%51.7)'ü antibiyotik reçete ederken baskı altında hissettiklerini ifade etti. II merkezi ve ilçelerde çalışan hekimlerimizi antibiyotik reçete etmelerini etkileyen faktörler açısından karşılaştırdığımızda, il merkezindeki hekimlerin antibiyotik reçete ederken daha çok baskı altında hissettiklerini tespit ettik ( $p>0.05)$.

Sonuç: Doktorların akılcı antibiyotik kullanımı hakkındaki bilgi, tutum ve davranışlarını anlamak, akılcı antibiyotik reçete etmeleri için oldukça önemlidir. Mezuniyet sonrası eğitim çalışmaları, hekimlerin antibiyotik reçete etmelerinde olumlu iyileştirmeler sağlayacaktır.

Anahtar kelimeler: Akılcı antibiyotik kullanımı; antibiyotik; aile hekimi; reçete yazma; antimikrobiyal direnç.

Sorumlu Yazar*: Handan ALAY, Atatürk Üniversitesi Tıp Fakültesi Hastanesi, Enfeksiyon Hastalıkları ve Klinik Mikrobiyoloji Anabilim dalı, Erzurum/TÜRKiYE E-posta: alayhandan@gmail.com

ORCID: 0000-0002-4406-014X

Gönderim: 30.10.2020 Kabul: 26.07.2021

Doi: $10.18663 /$ tjcl.817750 


\section{ABSTRACT}

Aim: Antimicrobial resistance resulting from non-rational use of antibiotics is a growing public health problem in Turkey and worldwide. In addition to patient-related factors, physicians' knowledge of and attitudes toward prescribing antibiotics also contribute to non-rational antibiotic use. The purpose of our study is to enhance physician awareness of rational use of antibiotics by determining the knowledge of and attitudes and behaviors toward antibiotic prescription of family physicians in our province.

Material and Methods: A 19-item questionnaire was prepared to investigate physicians' levels of knowledge and behaviors regarding antibiotic prescription. One hundred eighty physicians agreed to complete the questionnaire between 29.12.2018 and 01.05.2019.

Results: One hundred six (58.9\%) physicians were men and 74 (41.1\%) were women. Their mean age was $33 \pm 1$ (min 24 , max 50) years, and their mean length of service was $103 \pm 1$ ( $\min 1$, $\max 300)$ months. The mean number of patients seen in a day was $77 \pm 1$. One hundred thirty-seven (76.1\%) physicians were working in the province and $43(23.9 \%)$ in outlying districts. The most commonly encountered infection types were upper respiratory tract infections, reported by $134(37.5 \%)$, and urinary tract infections, reported by $61(17.1 \%)$. The most commonly prescribed antibiotics were beta lactam group drugs. One hundred nine physicians $(60.6 \%)$ reported receiving no training on rational antibiotic use after graduation, while $147(81.7 \%)$ described postgraduate in-service training seminars on rational use of antibiotics as useful. Ninety-three (51.7\%) reported feeling pressurized when issuing antibiotic prescriptions. Comparison of the physicians working in the province and in outlying districts in terms of antibiotic prescription behavior revealed that those in the province were felt more pressure while prescribing antibiotics ( $p>0.05)$.

Conclusion: Understanding physicians' knowledge of and attitudes and behaviors toward rational antibiotic use is important in terms of their rational antibiotic prescription behavior. Postgraduate educational seminars will have a positive impact on rational antibiotic prescription.

Keywords: Rational antibiotic use; antibiotic; family physicians; prescription; antimicrobial resistance.

\section{Giriş}

Antimikrobiyal direnç tüm dünyada ve ülkemizde giderek artan önemli bir sorundur [1, 2]. Uygunsuz antibiyotik tüketimi antimikrobiyal dirence katkı sağlamaktadır [3]. Mikroorganizmaların sık kullanılan antibiyotiklere direnç geliştirmesi; tedavi başarısızlıklarına, hastanın hastanede kalış süresinin uzamasına, tedavi maliyetlerinin artmasına, iş gücü kaybına ve mortalitede artışa neden olmaktadır [4, 5]. Antibiyotiklerin aşırı ve gereksiz tüketimi tüm dünyada olduğu gibi Türkiye'de de sağlık giderlerinin olumsuz etkilenmesine neden olmaktadır [6].

Dünya Sağlık Örgütü, ulusal ve yerel kuruluşların bilgilendirme çalışmalarına rağmen, Avrupa bölge ofisi tarafından yayınlanan bir rapora göre Türkiye Doğu Avrupa ülkeleri arasında antibiyotik tüketiminde ilk sırada yer almaktadır [7]. Alınan önlemlere rağmen antibiyotik kullanımında artışın önüne geçilememiştir. Hekimlerin antibiyotik reçete etmesini etkileyen birçok faktör vardır. Hasta baskısı, teknik imkanların kısıtlı olması ve tanı koymanın zorlaşması, aile hekimlerinin tecrübe ve bilgi eksikliği bu faktörler arasındadır. Bu bağlamda üst solunum yolu enfeksiyonları tüm dünyada gereksiz antibiyotiğin en sık reçete edildiği hastalıktır. Üst solunum yolu enfeksiyonlarının etiyolojisinde çoğunlukla viral etkenler söz konusudur [8, 9]. Viral enfeksiyonların sekonder bakteriyel enfeksiyonlara dönüşebileceği endişesi ve şüpheli bakteriyel enfeksiyonlarda antibiyotik reçete etmenin hastayı tatmin edeceği inancı hekimlerin gereksiz antibiyotik reçete etmelerine neden olmaktadır [10, 11].

Hastaya bağlı faktörlerin yanı sıra hekimlerin antibiyotik reçete etme konusundaki bilgi, tutum ve davranışları da uygunsuz antibiyotik kullanımını artırımaktadır. Bu çalışmada amacımız aile hekimlerinin antibiyotik reçete etme konusundaki bilgi, tutum ve davranışlarını belirleyerek akılcı antibiyotik kullanımı konusunda hekimlerin farkındalığını artırmaktır.

\section{Gereç ve Yöntemler}

\section{Anket Tasarımı}

Hekimlerin antibiyotik reçete etmedeki bilgileri düzeyleri ve davranışları konusunda 19 sorudan oluşan anket formu geliştirildi. Anket soruları hazırlanırken güncel literatürden faydalanılarak uzman ve yazarlarla fikir birliği yapıldı. Anket sorularının anlaşılabilirliği ve güvenilirliği açısından bir grup hekimde test edildi.Geri bildirimler sonucu gereklidüzenlemeler yapıldıktan sonra anket formu aile hekimlerine ulaştıııldı.

Anket formunda hekimlere sosyo-demografik özellikleriyle birlikte antibiyotik reçete etme davranışları, akılcı antibiyotik hakkındaki bilgi düzeyleri, antibiyotik reçete etmelerini etkileyen 
faktörler, akılcı antibiyotik hakkındaki eğitim durumları ve bilgi edindikleri kaynaklar hakkında sorular soruldu.

\section{Çalışmanın Tasarımı ve Örneklem Seçimi}

Çalışma Aralık 2018-Mayıs 2019 tarihleri arasında gerçekleştirildi. Etik kurul onayı ve II Sağlık Müdürlüğü'nden gerekli izin alındıktan sonra merkez ve ilçelerdeki aile hekimleri çalışma grubu olarak belirlendi. Il merkezinde 147 ve ilçelerde 127 olmak üzere toplam 274 aile hekimi olduğu belirlendi. Buna karşın teknik imkanlar nedeniyle aile hekimlerinin $210^{\prime}$ una ulaştırıldı. Ulaşılan hekimlerden 180'i anket formunu doldurmayı kabul etti.

\section{Veri Toplama}

Çalışmayı kabul eden hekimlere basılı form ve elektronik ortamda oluşturulan form ile yapıldı. Elektronik ortamda hazırlanan anket formu için kişiye özel tek erişim hakkı sunuldu.

\section{İstatistiksel analiz}

Veriler SPSS paket programı kullanılarak analiz edildi. Farklıııklar Chi-Squared testi ile test edildi. $\mathrm{P}$ değeri $<0.05$ olarak anlamlı olarak yorumlandı. Nicel verilerin analizi için bağımsız student-t testi kullanıldı.

\section{Bulgular}

Basılı ve elektronik ortamda hazırlanan anket formlarını il merkezinde 147, ilçelerde 127 olmak üzere toplamda 274 aile hekiminden 210 'una ulaştıralabildik. Fakat 180 hekim anketi doldurmayı kabul etti. Katılımcıların $106(\% 58,9)^{\prime}$ u erkek, 74 $(\% 41,1)^{\prime} i$ kadındı. Yaş ortalamaları 33 1 (min: 24- max: 50 ) yıl ve ortalama hizmet süreleri 103 \pm 1 (min:1-max:300) ay idi. Hekimlerin günlük hasta sayısı ortalaması $77 \pm 1$ idi. 137 $(\% 76,1)^{\prime}$ i il merkezinde, $43(\% 23,9)^{\prime}$ u ilçede görev yapmaktaydı. Katılımcıların demografik özellikleri tablo 1'de yer almaktadır.

\begin{tabular}{lcc}
\hline \multicolumn{3}{l}{ Tablo 1. Katılımcıların Demografik Özellikleri } \\
& Ortalama & (min.-maks.) \\
\hline Yaş & $33 \pm 1$ yıl & $(24-50$ yıl) \\
\hline Çalışma yılı & $103 \pm 1$ ay & $(1$ ay-25yıl) \\
Günlük Hasta Sayısı & $77 \pm 1$ & $(5-600)$ \\
& & $\mathrm{n}(\%)$ \\
Cinsiyet & Kadın & $74(41,1)$ \\
\hline Çalıştığı yer & Erkek & $106(58,9)$ \\
\hline
\end{tabular}

Bu çalışmada hekimlerin antibiyotik reçete etme davranışları, akılcı antibiyotik hakkındaki bilgi düzeyleri, antibiyotik reçete etmelerini etkileyen faktörler, akııı antibiyotik kullanımı hakkındaki eğitim durumları ve bilgi edindikleri kaynaklar sorgulanmıştır. Elde edilen veriler Tablo 2, 3, 4 ve 5'de detaylı olarak yer almaktadır.

\begin{tabular}{|c|c|c|c|}
\hline Sorular & & $\mathrm{n}$ & $\%$ \\
\hline \multirow{6}{*}{ En sık karşılaştığınız enfeksiyon tipi/tipleri hangileridir? } & Üst solunum yolu enfeksiyonu & 134 & 37,5 \\
\hline & Alt solunum yolu enfeksiyonu & 59 & 16,5 \\
\hline & Üriner sistem enfeksiyonu & 61 & 17,1 \\
\hline & Gastrointestinal sistem enfeksiyonu & 37 & 10,4 \\
\hline & Deri yumuşak doku enfeksiyonu & 55 & 15,4 \\
\hline & Genital enfeksiyonlar & 11 & 3,1 \\
\hline \multirow{14}{*}{ Hastalarınızda en sık reçete ettiğiniz antibiyotikler hangileridir? } & Penisilin & 32 & 8 \\
\hline & Ampisilin & 21 & 5,3 \\
\hline & Amoksisilin & 24 & 6 \\
\hline & Ampisilin-sulbaktam & 36 & 9 \\
\hline & Amoksisilin-klavulanik asit & 109 & 27,3 \\
\hline & Sefalosporinler & 65 & 16,3 \\
\hline & Klaritromisin & 40 & 10 \\
\hline & Azitromisin & 11 & 2,8 \\
\hline & Aminoglikozitler & 1 & 0,3 \\
\hline & Tetrasiklin & 4 & 1 \\
\hline & Trimetoprim-sulfametaksazol & 1 & 0,3 \\
\hline & Siprofloksasin & 39 & 9,8 \\
\hline & Levofloksasin & 9 & 2,3 \\
\hline & Moksifloksasin & 8 & 2 \\
\hline \multirow{5}{*}{$\begin{array}{l}\text { Üst solunum yolu enfeksiyonu tanısında antibiyotik başlarken } \\
\text { aşağıdaki kriterlerin hangisi/hangilerine başvuruyorsunuz? }\end{array}$} & Boğaz kültürü & 54 & 14,9 \\
\hline & Hemogram & 54 & 14,9 \\
\hline & CRP & 52 & 14,4 \\
\hline & Grup A streptekok hızlı antijen testi & 43 & 11,9 \\
\hline & Hastanın klinik ve fizik muayene bulgularını & 159 & 43,9 \\
\hline
\end{tabular}


Tablo 3. Hekimlerin Akılcı Antibiyotik Hakkında Bilgi Düzeylerinin Sorgulanması

Sorular

\begin{tabular}{|l|c|c|}
\hline Antibiyotiğin dokuya iyi geçmesi & $\mathrm{n}$ & $\%$ \\
\hline Antibiyotiğin uygun fiyatlı olması & 30 & 12 \\
\hline En etkin spektruma sahip olması & 12 & 4,8 \\
\hline Yan etkilerinin az olması & 29 & 11,6 \\
\hline Uygun endikasyonda kullanmak & 17 & 6,8 \\
\hline Uygun dozda ve uygun yerden uygulamak & 100 & 39,8 \\
\hline Akılıı antibiyotik kullanımı & 63 & 25,1 \\
\hline Aşılama & 142 & 22,1 \\
\hline El yıkama ve hijyen & 114 & 17,8 \\
\hline Teknolojik gelişimler & 130 & 20,2 \\
\hline Erken tanı ve teşhis & 38 & 5,9 \\
\hline Sağlıkla ilgili eğitimler ve farkındalığın artııılması & 102 & 15,9 \\
\hline Gebelik & 146 & 19,5 \\
\hline Yaş & 146 & 19,5 \\
\hline Alerji & 154 & 20,5 \\
\hline Kronik hastalıklar & 105 & 14,0 \\
\hline Kullandığı ilaçlar & 92 & 12,3 \\
\hline Daha önce antibiyotik kullanma durumu & 107 & 14,3 \\
\hline Evet & 51 & 28,3 \\
\hline Hayır & 101 & 56,1 \\
\hline Bilmiyorum & 28 & 15,6 \\
\hline Evet & 117 & 65,0 \\
\hline Hayır & 54 & 30,0 \\
\hline Bazen & 9 & 5,0 \\
\hline
\end{tabular}

Tablo 4. Hekimlerin Antibiyotik Reçete Etmelerini Etkileyen Faktörler

Sorular

Enfeksiyon hastalıklarında morbidite ve mortalitenin azalmasını

sağlayan faktör/faktörler nelerdir?

Viral enfeksiyonlarda antibiyotik kullanımı sekonder bakteri-

yel enfeksiyonların oluşmasına engel olur mu?

Hastalarınıza antibiyotik reçete ederken antibiyotiğin ekonomik boyutunu göz önünde bulunduruyormusunuz?

Hastalarınıza antibiyotik reçete ederken aşağıdaki kriterlerden hangisi/hangilerini dikkate alıyorsunuz?

Hastalara genellikle geniş spektrumlu antibiyotik reçete
edilmesinin nedeni sizce ne olabilir?

Bakteriyel enfeksiyon tanısını laboratuvar ile doğrulayamadığınızda antibiyotik reçete etmenize sebep olan en sık semptom veya bulgu hangisidir

Hastanıza reçete yazarken antibiyotik yazma konusunda kendinizi baskı altında hissediyor musunuz?

İş yükünüz yoğun olduğu zamanlarda hastayı da rahatlatmak adına antibiyotik reçete ediyor musunuz?

Hastaya antibiyotik reçete etmediğinizde hastanın "iyi doktor olmadığınızı ve hastalığını ciddiye almadığınızı" düşündüğü hissine kapılıyor musunuz?

\begin{tabular}{|l|c|c|}
\hline $\begin{array}{l}\text { Hastalık etkeninin tanısını ve antibiyogramını yapacak } \\
\text { kadar uzun sürenin olmaması }\end{array}$ & 101 & 38,3 \\
$\begin{array}{l}\text { Geniş spektrumlu antibiyotiklerin her türlü bakteri } \\
\text { cinsine karşı etkili olması }\end{array}$ & 40 & 15,2 \\
\hline $\begin{array}{l}\text { Tanı ve antibiyogram maliyeti ve ulaşılabilirlik yönün- } \\
\text { den uygun olmaması }\end{array}$ & 43 & 16,3 \\
\hline $\begin{array}{l}\text { Konu hakkında fazla bilgi olunmaması ve en hızlı seçenek } \\
\text { olarak geniş spektrumlu antibiyotik kullanılması }\end{array}$ & 80 & 30,3 \\
\hline Yüksek ateş & 109 & 28,2 \\
\hline Genel durum kötü olması & 86 & 22,3 \\
\hline Semptomların uzun süredir var olması & 53 & 13,7 \\
\hline Lenfadenopati olması & 57 & 14,8 \\
\hline Eksudatif tonsiller & 81 & 21 \\
\hline Evet & 93 & 51,7 \\
\hline Hayır & 87 & 48,3 \\
\hline Evet & 73 & 40,6 \\
\hline Hayır & 107 & 59,4 \\
\hline Evet & 107 & 59,4 \\
\hline Hayır & 73 & 40,6 \\
\hline
\end{tabular}




\begin{tabular}{|c|c|c|c|}
\hline Sorular & & $\mathrm{n}$ & $\%$ \\
\hline \multirow{4}{*}{$\begin{array}{l}\text { Akılcı antibiyotik kullanımı konusunda mezuniyet sonrası } \\
\text { eğitim aldınız mı? }\end{array}$} & Evet & 71 & 39,4 \\
\hline & Hayır, vakit bulamıyorum & 55 & 30,6 \\
\hline & $\begin{array}{l}\text { Hayır, bulunduğum bölgede hiç meslek içi } \\
\text { eğitim düzenlenmiyor }\end{array}$ & 52 & 28,9 \\
\hline & Hayır, eğitime ihtiyacım yok & 2 & 1,1 \\
\hline \multirow{2}{*}{$\begin{array}{l}\text { Akılcı antibiyotik kullanımı konusunda mezuniyet sonrası } \\
\text { hizmet içi eğitimlerin faydalı olduğunu düşünüyor musunuz? }\end{array}$} & Evet & 147 & 81,7 \\
\hline & Hayır & 33 & 18,3 \\
\hline \multirow{2}{*}{$\begin{array}{l}\text { Hastalara akılcı antibiyotik kullanımı konusunda eğitim ver- } \\
\text { ilmesi gerektiğini düşünüyor musunuz? }\end{array}$} & Evet & 168 & 93,3 \\
\hline & Hayır & 12 & 6,7 \\
\hline \multirow{2}{*}{$\begin{array}{l}\text { Hastalara akılcı antibiyotik kullanımı konusunda verilecek } \\
\text { eğitimin gereksiz antibiyotik kullanım oranlarını düşüreceğini } \\
\text { düşünüyor musunuz? }\end{array}$} & Evet & 164 & 91,1 \\
\hline & Hayır & 16 & 8,9 \\
\hline \multirow{4}{*}{$\begin{array}{l}\text { Antibiyotik reçete ederken herhangi bir bilgi kaynağına } \\
\text { başvuruyor musunuz? }\end{array}$} & İlaç bilgi bankası & 36 & 13,3 \\
\hline & Tanı ve tedavi rehberleri & 122 & 45,2 \\
\hline & İlaç firmalarının tanıtım afişleri & 23 & 8,5 \\
\hline & İnternet & 89 & 33 \\
\hline
\end{tabular}

Tablo 6. Hekimlerin Demografik Özelliklerinin ve Eğitim Alma Durumlarının Antibiyotik Reçete Etmelerini Etkileyen Faktörlerle Karşılaştırılması

\begin{tabular}{|c|c|c|c|c|c|c|c|c|c|c|c|}
\hline & & & \multicolumn{3}{|c|}{$\begin{array}{l}\text { Hastanıza reçete yazarken } \\
\text { antibiyotik yazma konusun- } \\
\text { da kendinizi baskı altında } \\
\text { hissediyor musunuz? }\end{array}$} & \multicolumn{3}{|c|}{$\begin{array}{l}\text { İş yükünüz yoğun } \\
\text { olduğu zamanlarda } \\
\text { hastayı da rahatlatmak } \\
\text { adına antibiyotik reçete } \\
\text { ediyor musunuz? }\end{array}$} & \multicolumn{3}{|c|}{$\begin{array}{l}\text { Hastaya antibiyotik reçete } \\
\text { etmediğinizde hastanın } \\
\text { "iyi doktor olmadığınızı } \\
\text { ve hastalığını ciddiye } \\
\text { almadığınızı" düşündüğü his } \\
\text { sine kapııııormusunuz? }\end{array}$} \\
\hline & & & Evet & Hayır & $p$ & Evet & Hayır & $\mathrm{p}$ & Evet & Hayır & $p$ \\
\hline \multirow{2}{*}{ Çalışma yılı* } & $\leq 6,5 \mathrm{yll}$ & $\mathrm{N}(\%)$ & $55(61,1)$ & $35(38,9)$ & \multirow{2}{*}{0,01} & $33(36,7)$ & $57(63,3)$ & \multirow{2}{*}{0,28} & $56(62,2)$ & $34(37,8)$ & \multirow{2}{*}{0,44} \\
\hline & $>6,5$ yıl & $\mathrm{N}(\%)$ & $38(42,2)$ & $52(57,8)$ & & $40(44,4)$ & $50(55,6)$ & & $51(56,7)$ & $39(43,3)$ & \\
\hline \multirow{2}{*}{$\begin{array}{l}\text { Günlük bakılan hasta } \\
\text { sayısı\# }\end{array}$} & $\leq 45$ & $\mathrm{~N}(\%)$ & $46(50,5)$ & $45(49,5)$ & \multirow{2}{*}{0,76} & $40 \quad(44)$ & $51 \quad(56)$ & \multirow{2}{*}{0,34} & $59(64,8)$ & $32(35,2)$ & \multirow{2}{*}{0,13} \\
\hline & $>45$ & N (\%) & $47(52,8)$ & $42(47,2)$ & & $33(37,1)$ & $56(62,9)$ & & $48(53,9)$ & $41(46,1)$ & \\
\hline \multirow{2}{*}{$\begin{array}{l}\text { Akılcı antibiyotik } \\
\text { kullanımı konusunda } \\
\text { mezuniyet sonrası } \\
\text { eğitim alma durumu }\end{array}$} & Evet & $\mathrm{N}(\%)$ & $30(42,3)$ & $41(57,7)$ & \multirow[b]{2}{*}{0,04} & $28(39,4)$ & $43(60,6)$ & \multirow[b]{2}{*}{0,8} & $43(60,6)$ & $28(39,4)$ & \multirow[b]{2}{*}{0,8} \\
\hline & Hayır & $\mathrm{N}(\%)$ & $63(57,8)$ & $46(42,2)$ & & $45(41,3)$ & $64(58,7)$ & & $64(58,7)$ & $45(41,3)$ & \\
\hline \multirow{2}{*}{ Çalıştığı yer } & ì & $\mathrm{N}(\%)$ & $76(55,5)$ & $61(44,5)$ & \multirow{2}{*}{0,06} & $54(39,4)$ & $83(60,6)$ & \multirow{2}{*}{0,59} & $79(57,7)$ & $58(42,3)$ & \multirow{2}{*}{0,38} \\
\hline & îlçe & $\mathrm{nN}(\%)$ & $17(39,5)$ & $26(60,5)$ & & $19(44,2)$ & $24(55,8)$ & & $28(65,1)$ & $15(34,9)$ & \\
\hline
\end{tabular}

\section{Tartışma}

Akılcı antibiyotik kullanımı tüm dünyada ve ülkemizde halk sağlığı açısından oldukça önemli bir konudur. Antimikrobiyal ajanlar, enfeksiyon hastalıklarında uygun endikasyonda kullanıldığında etkili klinik yanıt sağlamaktadırlar. Bunun aksine akılcı olmayan antimikrobiyal kullanımı sonucu gerek toplumda gerekse hastanede mikroorganizmaların direnç kazanmasına, tedavisi mümkün olmayan enfeksiyonlara, morbidite ve mortalite artışına neden olmaktadır. Bu çalışmada akılcı olmayan antibiyotik kullanımında ilk sıralarda yer alan ülkemizde, toplumda önemli bir hasta popülasyonuna hizmet veren aile hekimlerimizin akılcı antibiyotik reçete etme konusundaki bilgi, tutum ve davranışlarını tespit etmeyi amaçladık.

Birinci basamak sağlık hizmetlerinde en sık karşılaşılan enfeksiyonlar üst solunum yolu enfeksiyonları ve en sık reçete edilen antibiyotikler de beta laktam grubu antibiyotiklerdir [12]. Çalışmamızda yapılan çalışma ile uyumlu şekilde hekimlerin en sık karşılaştıkları enfeksiyonlar üst solunum yolu enfeksiyonu ve ikinci sıklıkta üriner sistem enfeksiyonları idi. En sık tercih edilen antibiyotikler beta laktam grubu antibiyotiklerdi. Tüm hekimler akılc antibiyotik kullanımı ve bilgileri konusunda tıp fakültesi eğitimi süresince ve sonrasında da kapsamlı bir şekilde 
eğitim almaktadırlar. Sürekli tıbbi eğitim hekimlerin antibiyotik reçete etmesini olumlu yönde etkilemektedir. Üst solunum yolu enfeksiyonlarında antibiyotik reçete etmek için klinisyenin tanı koymak için yeterli vakti olmasına karşın, çoğunlukla hekimler antibiyotik reçete etmek için hastanın klinik ve fizik muayene bulgularını kullanmaktadırlar. Yapılan birçok çalışmada hekimlerin bilgi düzeyinin, antibiyotik reçete etmelerini etkileyen önemli bir faktör olduğu gösterilmiştir [13, 14]. Çalışmamızda da hekimlerimiz tanı koymak için sıklıkla hastanın klinik ve fizik muayene bulgularını kullandıklarını ifade ettiler.

Akılcı antibiyotik kullanımı hakkında hekimlerin bilgi düzeylerinin iyi olmasına karşın uygulamaların mükemmel olmadığını görmekteyiz. Çalışmamızda hekimlerimizde akılcı antibiyotik kullanımı hakkındaki bilgi düzeylerini değerlendirmek için sorular sorduk. "Akılcı antibiyotik kullanımı denildiğinde aklınıza gelen ilk şey nedir?" sorusuna hekimlerin çoğunluğu uygun endikasyonda kullanmak, uygun dozda ve uygun yerde kullanmak olarak cevap verdi. "Enfeksiyon hastalıklarında mortalite ve morbiditenin azaltılmasında etkili olan faktörler nelerdir?" sorusunun cevabında, akılcı antibiyotik kullanımı, el yıkama ve hijyen, erken tanı ve teşhis, aşılama, sağlıkla ilgili eğitimler ve farkındalığın artırılması ilk sıralarda yer aldı. Anket sonuçlarına göre, hekimlerin çoğunluğu viral enfeksiyonlarda antibiyotik kullanımının sekonder bakteriyel enfeksiyonların oluşmasını engellemediğini, antibiyotik reçete ederken hastalara ait bir takım faktörleri ve antibiyotiğin ekonomik boyutunu göz önünde bulundurduklarını ifade ettiler.

Yapılan birçok çalışmada, hekimlerin antibiyotik reçete etmelerini etkileyen faktörler araştırılmıştır. Niteliksel sistematik bir çalışmada, hekimlerin antibiyotik reçete etmelerini etkileyen faktörler arasında hastayı kaybetme korkusu, hasta tarafından hızlı bir şekilde iyileşme isteği, zaman baskısı, ilaç firmalarının etkileri ve teşhis olanaklarının yetersiz olması yer almaktadır [15]. Bu çalışmanın sonuçlarına paralel bir şekilde çalışmamızda, hekimlerin tanı için yeterli sürenin olmaması, hastanın genel durumunun bozuk ve yüksek ateşinin olması antibiyotik reçete etmesini etkileyen faktörler arasında idi. Hekimlerin neredeyse yarıya yakını antibiyotik reçete ederken kendilerini baskı altında hissettiklerini ve iyi doktor olmadıkları hissine kapıldıklarını belirttiler. Hekimlerin iyi hasta-hekim ilişkisini sürdürmek ve bu yönde hastaların beklentilerine karşılık vermek istemeleri akılcı olmayan antibiyotik kullanımına neden olmaktadır. Dünya çapında birçok ülkede hastaların viral hastalıkların tedavisinde antibiyotik kullanma oranları yüksek tespit edilmiştir [16]. Bu sonuçlar hasta memnuniyetini sağlamak adına hekimlerin akılcı olmayan antibiyotik reçete ettiklerini göstermektedir.

Hekimlerin iş yoğunluğu nedeniyle hastalara ayırdıkları süre daha kısa olmaktadır. Hasta başına ayrılan ortalama süre kısaldıkça, hekim hastayı memnun etmek ve yoğunluğu azaltmak için antibiyotik reçete etmektedir [17]. Çalışmamızda hekimlerin yaklaşık yarısı iş yoğunluğu nedeniyle antibiyotik reçete etmektedir. Yoğun iş yükünün olduğu durumlarda hastalara gecikmeli reçete yazmak hekimin doğru karar vermesini sağlayarak hasta memnuniyetini artıran bir uygulama olabilir. Yapılan bir çalışmada, gecikmeli reçete yazmanın hasta ve doktor tarafından memnun bir uygulama olduğu sonucuna varmıştır. Aynı çalışmanın sonucunda sinüzit, otit gibi vakalarda gecikmeli reçete yazımının uygulanabilir bir strateji olduğu ve bu konuda eğitimlerde yer verilmesi gerektiği de vurgulanmaktadır [18].

Çalışmamızda hekimlerimizin büyük çoğunluğu mezuniyet sonrası eğitim almadıklarını ifade ettiler. Eğitim almayanların yarısı ise mezuniyet sonrası eğitimlerin düzenlenmediğini belirttiler. Mezuniyet sonrası hizmet içi eğitimlerin verilmesi gerektiğini ve antibiyotik reçete ederken çoğunlukla tanı ve tedavi rehberlerini kullandıklarını çalışmamızın sonuçlarından anlamaktayız. Hekimlerin antibiyotik kullanımı konusunda bilgi ve tutumları, akılcı antibiyotik reçete etmesi için oldukça önemlidir. Yapılan bir retrospektif kohort çalışmada bu sonucu destekler niteliktedir [13]. Tıp fakültesi eğitimi sırasında alınan eğitimler, mezuniyet sonrası da devam ettirilmelidir. Antibiyotiklerin etkileri, antibiyotik direnci, antibiyotik reçete etmesini etkileyen faktörleri ve başvurulacak tedavi kılavuzları konusundaki hekimlerin bilgi ve tutumlarını geliştirecek konular akılcı antibiyotik yönetiminde başarılı olacaktır. Yapılan bir çalışmada aile hekimlerinin antibiyotik tedavisi için tanı kılavuzlarını kullanmaları çalışmamız sonucu ile uyumludur [19]. Çalışmamızda hekimlerin demografik özellikleri ve eğitim alma durumları antibiyotik reçete etmelerini etkileyen faktörlerle karşılaştırıldı (Tablo 6). Çalışma yılı daha fazla olan hekimler daha az baskı altında hissettiklerini ifade ettiler $(p=0.01)$. Çalışma yılı daha az olan hekimler "hastaya antibiyotik reçete etmediklerinde iyi doktor olmadığınız ve hastalığını ciddiye almadığınız hissine" kapılma durumu daha fazla idi fakat fark istatistiksel olarak anlamlı değildi ( $p>0.05)$. Çalışmamızda günlük bakılan hasta sayısı fazla olan $(p>0.05)$ ve mezuniyet sonrası eğitim almayan hekimler (p:0.04) daha fazla baskı altında hissetmekteydiler ( $p=0.04)$.

II merkezinde yaşayan hekimler için daha iyi gelişmiş iş ve sosyal etkileşim, ulaşım imkanları, daha iyi eğitim imkanları ve yaşam tarzına sahiptirler. Kırsal kesimde yaşayan insanlar ise sosyal ve kültürel olarak merkezde yaşayanlara göre bu imkanlardan daha az yararlanmaktadırlar. Bu fark hekimlerin hastayla iletişimini etkileyip antibiyotik reçete etme algısını etkileyebilir. Aksine çalışmamızda il merkezi ve ilçelerde çalışan 
hekimlerimizi antibiyotik reçete etmelerini etkileyen faktörlere göre karşılaştırdığımızda, il merkezindeki hekimlerin olumsuz yönde daha çok etkilendiğini tespit ettik fakat fark istatistiksel olarak anlamlı değildi ( $p>0.05$ ). Antibiyotik yazma konusunda daha fazla baskı altında hissetmeleri, işyükü yoğunluğuna bağlı olarak hastayı rahatlatmak adına antibiyotik reçete etmeleri ve antibiyotik reçete etmediklerinde iyi doktor olmadıkları hissine kapılmaları, il merkezinde sosyokültürel seviyesi yüksek hastaların hekimler üzerine antibiyotik yazmaları konusunda daha fazla baskı uyguladıklarını düşündürmektedir. Birinci basamak sağlık hizmetinde çalışan hekimlerde yapılan bir çalışmada, hekimlerin antibiyotik kullanımı konusundaki bilgi, tutum ve uygulamalarının kırsal ve merkezde yaşayan hekimlerde farklılık olmadığını göstermiştir [20].

\section{Sonuç}

Birinci basamak sağlık kuruluşları, üst solunum yolu enfeksiyonlarına bağlı antibiyotiğin sıklıkla reçete edildiği birimlerdir. Doktorların akılcı antibiyotik kullanımı hakkındaki bilgi, tutum ve davranışlarını anlamak, akılcı antibiyotik reçete etmeleri için oldukça önemlidir. Mezuniyet sonrası eğitim çalışmaları, hekimlerin antibiyotik reçete etmelerinde olumlu iyileştirmeler sağlayacaktır. Ayrıca üst solunum yolları enfeksiyonu, üriner sistem enfeksiyonu gibi sık görülen enfeksiyon hastalıklarının tanılarını koymaya yardımcı laboratuvar olanaklarının artırılması akılcı antibiyotik reçete etmeyi olumlu yönde katkı sağlayacaktır.

Çıkar çatışması/finansal destek beyanı

Çalışmayı maddi olarak destekleyen kişi/kuruluş yoktur ve yazarların herhangi bir çıkar dayalı ilişkisi yoktur.

\section{Kaynaklar}

1. World Health Organization. Global Antimicrobial Resistance Surveillance System (GLASS) Report. 2017

2. Harbarth S, Balkhy $\mathrm{HH}$, Goossens $\mathrm{H}$, et al. Antimicrobial resistance: one world, one fight. Antimicrob Resist Infect Control. 2015; 4: 49.

3. Laxminarayan R, Duse A, Wattal C, et al. Antibiotic resistance-the need for global solutions. Lancet Infect Dis. 2013; 13: 1057-98.

4. French GL. Clinical impact and relevance of antibiotic resistance. Adv Drug Deliv Rev. 2005 ; 57: 1514-27.

5. Little P, Gould C, Williamson I, et al. Reattendance and complications in a randomised trial of prescribing strategies for sore throat: the medicalising effect of prescribing antibiotics. BMJ. 1997; 315: 350-2.

6. Karatas $Y$, Dinler B, Erdoğdu T, et al. Evaluation of drug use attitudes of patient and its relatives attending to Cukurova University Medical faculty Balcalı Hospital. Cukurova Medical Journal. 2012; 37: 1-8.
7. Antibiotic use in eastern Europe: a cross-national database study in coordination with the WHO Regional Office for Europe. Lancet Infect Dis. 2014; 14: 381-7.

8. Bauman KA. The family physician's reasonable approach to upper respiratory tract infection care for this century. Arch Fam Med. 2000; 9: 596-597.

9. Gonzales R, Malone DC, Maselli JH, et al. Excessive antibiotic use for acute respiratory infections in the united states. Clin Infect Dis. 2001; 33: 757-62.

10. Mangione-Smith R, McGlynn EA, Elliott MN, et al. Parent expectations for antibiotics, physician-parent communication, and satisfaction. Arch Pediatr Adolesc Med. 2001; 155: 800-6.

11. Stivers T, Mangione-Smith R, Elliott MN, et al. Why do physicians think parents expect antibiotics? What parents report vs what physicians believe. J Fam Pract. 2003; 52: 140-8.

12. Karabay $\mathrm{O}$, Özdemir D, Güçlü E, et al. Attitudes and behaviors of Family Physicians regarding use of antibiotics. Journal of Microbiology and Infectious Diseases. 2011; 1: 53-7.

13. Gonzalez-Gonzalez C, López-Vázquez P, Vázquez-Lago JM, et al. Effect of physicians attitudes and knowledge on the quality of antibiotic prescription: A Cohort study. PLoS One 2015; 10: 141820.

14. Thriemer $\mathrm{K}$, Katuala $\mathrm{Y}$, Batoko $\mathrm{B}$, et al. Antibiotic prescribing in DR congo: A knowledge, attitude and practice survey among medical doctors and students. PLoS One 2013; 8: 55495.

15. Teixeira Rodrigues A, Roque F, Falcão A, et al. Understanding physician antibiotic prescribing behaviour: A systematic review of qualitative studies. Int J Antimicrob Agents. 2013; 41: 203-12.

16. European Commission. Antimicrobial resistance. Eurobarometer 338/Wave 72.5-TNS Opinion and Social. Luxembourg: European Commission; 2010.

17. Cadieux G, Tamblyn R, Dauphinee D, et al. Predictors of inappropriate antibiotic prescribing among primary care physicians. Can Med Assoc J. 2007; 177: 877-83.

18. Høye S, Frich JC, Lindbæk M. Use and feasibility of delayed prescribing for respiratory tract infections: A questionnaire survey. BMC Fam Pract. 2011; 12: 34.

19. Salm F, Schneider S, Schmücker K, et al. Antibiotic prescribing behavior among general practitioners - a questionnaire-based study in Germany. BMC Infectious Diseases. 2018; 18: 208.

20. Al-Homaidan HT, Barrimah IE. Physicians' knowledge, expectations, and practice regarding antibiotic use in primary health care. Int J Health Sci (Qassim). 2018; 12: 18-24. 